\title{
PREPARATION AND EVALUATION OF PHYSICAL AND CHEMICAL PROPERTIES OF GLUTEN-FREE BISCUITS
}

\author{
Hadeer A.A. Abd El-Hamid ${ }^{1}$,Abdel-Gawad M.M. El-Shawaf', Attia M.A. \\ El-Makhzangy ${ }^{1}$ and Ahmed M.S. Hussein ${ }^{2}$ \\ ${ }^{1}$ Food \& Dairy Sci. Dept., Faculty of Technology and Development, \\ Zagazig Univ., Egypt. \\ ${ }^{2}$ Food Technology Dept, National Research Centre, Dokki, 12311, Giza, \\ Egypt.
}

\section{ABSTRACT}

This study was carried out to use whole meal quinoa flour, papaya powder, gelatinized corn flour, rice flour, defatted soya flour and potato starch for production of gluten-free biscuits suitable for celiac patients. Carboxy methyl cellulose $(C M C)$ was used to improve the quality of gluten-free biscuits at level of 0.1\%. Biscuit made of $100 \%$ wheat flour (WF) $72 \%$ extraction was prepared for comparison. Chemical composition, mineral contents of basic raw materials and rheological properties of used mixtures were determined, also, the chemical composition, mineral content and physical properties (color values, baking quality and sensory attributes) for final products were evaluated.

The results showed that, papaya powder contained the highest value of crude fiber, calcium and iron content, and this increase was reflected in the increasing of the same aforementioned components in the final product with the increasing level of papaya powder. Also, quinoa flour contained the higher value of protein, ash, fiber, zinc, iron and calcium compared to wheat flour. And through the evaluating the quality of the final product the results indicated that no evident discrepancy was observed for instrumental weight, volume, diameters and thickness between the control biscuit and the gluten free biscuit samples according to statistical analysis. On other hand, the results indicated that, in terms of the color of final product was tends to darkness with the increasing ratio of papaya powder (decrease $L^{*}$ value), on contrary of redness $\left(a^{*}\right)$ values which increased in the produced gluten free biscuit samples.

Sensory evaluation of gluten free biscuits indicated that all samples were acceptable, but sample which contained whole meal quinoa flour, papaya powder, gelatinized corn flour, rice flour, defatted soya flour and potato starch at ratio 20:20:15:15:15:15 
respectively had superior sensory characteristics compared to other gluten free samples and highly nutritional value compared to control (100\% wheat flour) and suitable for celiac patients.

Key words: Celiac disease, Wheat flour, Gluten free biscuit, Quinoa flour and Papaya powder.

\section{INTRODUCTION}

The celiac disease is a genetically predisposed autoimmune disorder that results in damage to the lining of the small intestine when foods with gluten are eaten (Mirhosseini et al., 2015). Nowadays, there is a high demand for the development of food products that increase the availability of gluten-free food in order to attend an increasing demand. This constitutes an actual technological challenge with a wide possibility for investigation (Sansone et al., 2013; Rinaldoni et al., 2014). Although wheat flour baked goods are consumed worldwide, some individuals present intolerance to the prolamins (celiac patients) of wheat, and to other cereal grains such as rye, oats and barley. This intolerance, called celiac disease, seriously impairs intestinal absorption and can lead to a severe malnutrition (Waszczuk et al., 2007; Niewinski, 2008).

Cereal-based crackers, cookies, and breakfast cereals are the products that an important source of energy for human nutrition. Cookies are widely consumed in many countries because they have a broad range of the choices to be enjoyed as a snack with low cost and longer shelf life (Abdel-Moemin, 2015).

Quinoa (Chenopodium quinoa Willd.) flat, oval-shaped seeds that are usually pale yellow but can range in color from pink to black (Karyotis et al., 2003). Quinoa is a grain with exceptional nutritional value which has high concentrations of protein, all essential amino acids, unsaturated fatty acids, and a low glycemic index (GI), it also contains minerals, vitamins, and other beneficial compounds, and is gluten-free. Quinoa is easy to cook also has versatility in preparation (Vega-Gálvez et al., 2010; Tang et al., 2015).

The world production of papaya fruits (Carica papaya L.) in 2008 was estimated to be approximately 9.1 million tonnes (FAOSTAT, 2008). Papaya is a good source of vitamins, minerals and fiber (Roberts et al., 2008). Therefore, the fruit pulp of papaya is usually consumed as fresh slices, and it can be processed and used in more variety of products, such as bakery products (Adubofuor et al., 2012).

Therefore, the aim of this study was to develop gluten-free biscuit from whole meal quinoa flour and papaya powder as an alternative to wheat flour to meet the need of people with celiac disease, and evaluation of 
the impact of these alternative materials on physical, chemical and organoleptic properties of biscuit.

\section{MATERIALS AND METHODS}

\section{Materials}

Wheat flour (72\% extraction), rice flour (commercial name Zamzam), papaya fruits, potato starch, shortening, ground sugar, vanilla powder, eggs, salt, Cream of tartar, Ammonium bicarbonate and Sodium bicarbonate were purchased from the local market. Quinoa seed sample (grown in Egypt in 2016 season) was purchased from the ministry of agriculture in season 2016-2017 and kept at $3-4^{\circ} \mathrm{C}$ until used in technological studies. Corn grains (Zea mays L.) were purchased from the Corn Breeding Section, Field Company, Egypt. Defatted soy flour was obtained from the Agriculture Research Center, Giza, Egypt. Calcium hydroxide and carboxy methyl cellulose (CMC) supplied by Degussa Texturant Systems, Germany.

\section{Methods}

\section{Preparation of gelatinization corn flour}

Laboratory process for preparing dry corn masa was performed according to Vidal-Quintanar et al. (2001) with some modifications as reported by Hussein et al. (2011) as follows: The whole white corn grains and $1 \%$ calcium hydroxide solution were mixed in ratio of $1: 3(\mathrm{w} / \mathrm{w})$ and then cooked at $95{ }^{\circ} \mathrm{C}$ for $95 \mathrm{~min}$ on an electronic. The resulted nixtamal was steeped over night $(15 \mathrm{~h})$ at $24 \pm 1^{\circ} \mathrm{C}$ then, washed with $(5 \mathrm{~L})$ tap water followed by decantation using a sieve. The washing process was repeated three times to remove excess lime and pericarp. The wet masa was spread on aluminum foil in a layer of $2.5 \mathrm{~cm}$ thickness then dried in convection oven adjusted to $85{ }^{\circ} \mathrm{C}$ for about $6 \mathrm{~h}$ with occasional mixing. The dry masa was milled in Chopin CD1 mill to pass through a 40 mesh screen $(420 \mu \mathrm{m})$. The obtained masa was packed in polyethylene bags and the bags were stored in a refrigerator $\left(4^{\circ} \mathrm{C}\right)$ until used.

\section{Preparation of quinoa flour}

Quinoa flour was prepared according to Al Shehry (2016) with some modifications. The seeds were washed many times with tap water to remove saponins until there was no more foam in the washing water, then dried in an air ventilation oven (SHEL LAB $1370 \mathrm{FX}$, Germany) at $50^{\circ} \mathrm{C}$ until dried. Quinoa seeds were ground to fine powder in an electric grinder (Quadrumat Junior flour mill, Model Type No: 279002, (CBrabender ® OHG, Duisburg 1979 , Germany) and sifted through a 60 mesh, stored at $4 \pm 1^{\circ} \mathrm{C}$ until used. 


\section{Preparation of papaya powder}

The papaya powder is prepared from fresh papaya according to Varastegani et al. (2015) with some modification. As follows: papaya fruits were washed with tap water and peeled manually, seeds were removed and the pulp was cut into small slices $(0.5$ to $1 \mathrm{~cm}$ thick) then slices dried in oven at $60^{\circ} \mathrm{C}$ for $24 \mathrm{~h}$. The dried slices were milled to fine powder using a bench-top grinder and sieved to pass through 60 mesh, packed in polyethylene bags. The bags were stored in a refrigerator $\left(4 \pm 1^{\circ} \mathrm{C}\right)$ until used.

\section{Analytical methods \\ Chemical composition}

Moisture, ash, fiber, protein and fat contents of raw materials and different biscuits were determined according to AACC (2000). Total carbohydrates were calculated by difference: 100 - (protein + fat + fiber + ash). Individual elements (Calcium, zinc and iron) contents in all samples were determined according to the method described by Chapman and Pratt (1962).

\section{Rheological properties}

Rheological properties of doughs were evaluated using viscoamylograph test according to A.A.C.C. (2000).

\section{Processing of gluten-free biscuits}

Gluten free biscuits preparation was carried out according to the method of Schober et al. (2003) with some modifications. The ingredients were weighed according to the recipes in Table (1). The eggs were initially homogenized with a hand blender (Braun, Kronberg, Germany) for a few seconds. Then, sugar, shortening and egg were mixed for $20 \mathrm{sec}$. at speed 3 . Half of the flour and all other ingredients were then included and mixed for $20 \mathrm{sec}$. The remaining flour was added and mixed for $140 \mathrm{sec}$. to give a total mixing time of $3 \mathrm{~min}$. Following a rest time of $20 \mathrm{~min}$, then the dough was sheeted for $5 \mathrm{~mm}$ thickening with a diameter of $50 \mathrm{~mm}$. Biscuits formed manually and baked at $180{ }^{\circ} \mathrm{C}$ for $20 \mathrm{~min}$ in laboratory oven. The biscuits cooled at room temperature for $75 \mathrm{~min}$.

\section{Baking quality of gluten-free biscuits}

Diameter (D) was measured by Boclase (HL 474938, STECO, Germany). Also, volume (V) and thickness (T) of biscuits were determined according to standard methods described in A.A.C.C. (2000). The spread 
ratio $\mathrm{D} / \mathrm{T}$ was calculated by dividing the average value of diameter by the average value of thickness of gluten free biscuits.

Table 1: Composition of mixtures used in manufacture of biscuits.

\begin{tabular}{|l|c|c|c|c|c|c|}
\hline \multirow{2}{*}{ Ingredients (gm) } & \multicolumn{7}{|c|}{ Formulas } \\
\cline { 2 - 7 } & Control & $\mathbf{1}$ & $\mathbf{2}$ & $\mathbf{3}$ & $\mathbf{4}$ & $\mathbf{5}$ \\
\hline Wheat flour (72\%) & 100 & - & -- & -- & -- & - \\
\hline Quinoa Flour & -- & 40 & 30 & 20 & 10 & -- \\
\hline Papaya powder & -- & - & 10 & 20 & 30 & 40 \\
\hline Rice flour & -- & 15 & 15 & 15 & 15 & 15 \\
\hline Gelatinized corn flour & -- & 15 & 15 & 15 & 15 & 15 \\
\hline Defatted Soy flour & -- & 15 & 15 & 15 & 15 & 15 \\
\hline Potato starch & -- & 15 & 15 & 15 & 15 & 15 \\
\hline Cream of tartar & 0.1 & 0.1 & 0.1 & 0.1 & 0.1 & 0.1 \\
\hline Shortening & 28 & 28 & 28 & 28 & 28 & 28 \\
\hline Ammonium bicarbonate & 0.1 & 0.1 & 0.1 & 0.1 & 0.1 & 0.1 \\
\hline Carboxy methyl cellulose & -- & 0.1 & 0.1 & 0.1 & 0.1 & 0.1 \\
\hline Eggs & 27.5 & 27.5 & 27.5 & 27.5 & 27.5 & 27.5 \\
\hline Vanilla & 1 & 1 & 1 & 1 & 1 & 1 \\
\hline Sugar & 35 & 35 & 35 & 35 & 35 & 35 \\
\hline Sodium bicarbonate & 2 & 2 & 2 & 2 & 2 & 2 \\
\hline Salt & 0.91 & 0.91 & 0.91 & 0.91 & 0.91 & 0.91 \\
\hline
\end{tabular}

\section{Color determination}

Surface gluten free biscuit color was measured according to Sapers and Douglas (1987). Hunter $\mathrm{L}^{*}, \mathrm{a}^{*}$ and $\mathrm{b}^{*}$ (lightness, redness and yellowness, respectively) parameters were measured with a color difference meter using a spectro-colorimeter (Tristimulus Color Machine) with the CIE lab color scale (Hunter, Lab Scan XE - Reston VA, USA) in the reflection mode. The instrument was standardized each time with white tile of Hunter Lab Color Standard (LX No.16379): $\mathrm{X}=72.26, \mathrm{Y}=81.94$ and $\mathrm{Z}=88.14$ $\left(L^{*}=92.46 ; a^{*}=-0.86 ; b^{*}=-0.16\right)$.

\section{Organoleptic characteristics of biscuit}


Biscuit samples were organoleptically evaluated by ten panelists (male and female) for its sensory characteristics: appearance, color, odor, texture, taste and overall acceptability as the method described by Larmond (1977). The maximum score of each attribute was (20) degrees.

\section{Statistical analysis}

The obtained results were statistically analyzed using SPSS statistical package (Version 20) according to Rattanathanalerk et al. (2005), analysis of variance (ANOVA). Duncan's multiple range test and least significant difference (LSD) was chosen to determine any significant difference among various treatments at $\mathrm{P}<0.05$.

\section{RESULTS AND DISCUSSION}

\section{Chemical composition of raw materials}

Proximate Composition of raw materials under study i.e., wheat flour (72\% extraction), Quinoa flour, fresh papaya, rice flour, gelatinized corn flour (GCF), defatted soy flour and potato starch were evaluated for their chemical composition as shown in Table (2).

The obtained results showed that, fresh papaya had the highest value of moisture content $(85.94 \%)$ and fiber $(12.45 \%)$ on dry basis. While the highest value of protein and ash contents were recorded by defatted soy flour $(36.76 \%$ and $4.33 \%$ ), respectively in compared to potato starch that recorded the lowest value of protein content $(0.11 \%)$ followed by rice flour $(7.25 \%)$. Concerning fat content, the highest value was recorded by quinoa flour $(5.25 \%)$ followed by gelatinized corn flour $(4.15 \%)$.

The obtained results nearly agreed with those of Sharoba et al. (2009). They determined the chemical composition of wheat flour $72 \%$ ex. and found that the contents of moisture, protein, fat, ash, crude fiber and available carbohydrates were $11.99 \%, 11.85 \%, 1.06 \%, 0.52 \%, 0.54 \%$ and $86.04 \%$ respectively. Also, these results were in agreement with those of Abou-Zaid et al. (2012) they determined the chemical composition of crude quinoa and reported that it contained $11.65 \%$ moisture, $14.10 \%$ protein, $5.90 \%$ fat, $3.79 \%$ ash, $4.35 \%$ crude fiber and $71.86 \%$ total carbohydrates.

Concerning the results of papaya powder, the percentage of crude fiber was in agreement with those reported by Puwastien et al. (2000) and USDA (2009) they reported that total dietary fiber content of ripe papaya fruit varies from 11.9 to $21.5 \mathrm{~g} / 100 \mathrm{~g}$ dry matter, crude protein content ranges from 3.74 to $8.26 \mathrm{~g} / 100 \mathrm{~g}$ dry matter and the total lipid content varies between 0.92 and $2.2 \mathrm{~g} / 100 \mathrm{~g}$ dry matter. 
Table (2): Chemical composition of raw materials (on dry weight basis).

\begin{tabular}{|l|c|c|c|c|c|c|}
\hline \multirow{2}{*}{ Samples } & \multicolumn{5}{c|}{ Chemical composition (g/100g) } \\
\cline { 2 - 7 } & Moisture & Protein & Fat & Fiber & Ash & Carbohydrates \\
\hline Wheat flour & $12.95^{\mathrm{c}}$ & $10.66^{\mathrm{c}}$ & $1.18^{\mathrm{d}}$ & $0.61^{\mathrm{e}}$ & $0.57^{\mathrm{e}}$ & $86.98^{\mathrm{b}}$ \\
\hline Quinoa & $12.63^{\mathrm{c}}$ & $15.55^{\mathrm{b}}$ & $5.25^{\mathrm{a}}$ & $3.62^{\mathrm{c}}$ & $3.58^{\mathrm{c}}$ & $72.00^{\mathrm{d}}$ \\
\hline Papaya & $85.94^{\mathrm{a}}$ & $9.39^{\mathrm{d}}$ & $0.10^{\mathrm{e}}$ & $12.45^{\mathrm{a}}$ & $3.90^{\mathrm{b}}$ & $74.16^{\mathrm{d}}$ \\
\hline Rice flour & $11.55^{\mathrm{d}}$ & $7.25^{\mathrm{f}}$ & $1.44^{\mathrm{d}}$ & $2.15^{\mathrm{d}}$ & $0.65^{\mathrm{e}}$ & $88.51^{\mathrm{b}}$ \\
\hline $\begin{array}{l}\text { Gelatinized corn } \\
\text { flour }\end{array}$ & $10.89^{\mathrm{e}}$ & $8.87^{\mathrm{e}}$ & $4.15^{\mathrm{b}}$ & $4.80^{\mathrm{b}}$ & $3.34^{\mathrm{d}}$ & $78.84^{\mathrm{c}}$ \\
\hline $\begin{array}{l}\text { Defatted soy } \\
\text { floww }\end{array}$ & $12.23^{\mathrm{c}, \mathrm{d}}$ & $36.76^{\mathrm{a}}$ & $2.33^{\mathrm{c}}$ & $3.52^{\mathrm{c}}$ & $4.33^{\mathrm{a}}$ & $53.06^{\mathrm{e}}$ \\
\hline Potato starch & $14.11^{\mathrm{b}}$ & $0.11^{\mathrm{g}}$ & $\mathrm{ND}$ & $\mathrm{ND}$ & $\mathrm{ND}$ & $99.89^{\mathrm{a}}$ \\
\hline LSD at 0.05 & $\mathbf{0 . 7 2 0}$ & $\mathbf{0 . 2 4 9}$ & $\mathbf{0 . 5 7 4}$ & $\mathbf{0 . 4 2 5}$ & $\mathbf{0 . 1 6 1}$ & $\mathbf{4 . 2 1 5}^{\mathrm{a}}$ \\
\hline
\end{tabular}

The same letter in the same column are not significantly different at $\mathrm{P} \leq 0.05$.

N.D. $=$ not detected.

\section{Mineral contents of raw materials}

Table (3) presented some mineral contents of raw materials (Calcium, iron and zinc) and the obtained results referred to the highest value of calcium content $(228.0 \mathrm{mg} / 100 \mathrm{~g})$ was investigated by papaya powder followed by quinoa flour $(77.70 \mathrm{mg} / 100 \mathrm{~g})$, also papaya powder recorded the highest value of iron content $(7.18 \mathrm{mg} / 100 \mathrm{~g})$ on the contrary to wheat flour which recorded the lowest value of iron content $(0.83 \mathrm{mg} / 100 \mathrm{~g})$.

Table (3): Mineral content of basic materials (on dry weight basis).

\begin{tabular}{|c|c|c|c|}
\hline \multirow{2}{*}{ Samples } & \multicolumn{3}{|c|}{ Mineral content (mg/100g) } \\
\cline { 2 - 4 } & Ca & Fe & Zn \\
\hline Wheat flour & $25.40^{\mathrm{c}}$ & $0.83^{\mathrm{c}}$ & $1.54^{\mathrm{b}}$ \\
\hline Quinoa flour & $77.70^{\mathrm{b}}$ & $5.70^{\mathrm{b}}$ & $4.93^{\mathrm{a}}$ \\
\hline Papaya & $228.0^{\mathrm{a}}$ & $7.18^{\mathrm{a}}$ & $0.39^{\mathrm{c}}$ \\
\hline LSD at $\mathbf{0 . 0 5}$ & $\mathbf{9 . 8 7 2}$ & $\mathbf{0 . 7 8 8}$ & $\mathbf{0 . 0 3 2}$ \\
\hline
\end{tabular}


The same letter in the same column are not significantly different at $\mathrm{P} \leq 0.05$.

However, the lowest value of zinc content was recorded by papaya powder $(0.39 \mathrm{mg} / 100 \mathrm{~g})$. While the highest value of zinc content was recorded by quinoa flour $(4.93 \mathrm{mg} / 100 \mathrm{~g})$. The result of iron content in wheat flour was in agreement with Sharoba et al. (2009) and Abou-Zaid et al. (2012) they reported that the iron content in wheat flour $0.71 \mathrm{mg} / 100 \mathrm{~g}$ and $0.73 \mathrm{mg} / 100$ respectively. Also, the results of detected mineral contents of papaya ( $\mathrm{Ca}, \mathrm{Fe}$ and $\mathrm{Zn}$ ) were in a harmony with the results which reported by the QECD (2010) where their results indicated the calcium, iron and zinc content in papaya varieties were ranged between $57.93 \mathrm{mg} / 100 \mathrm{~g}$ $285.93 \mathrm{mg} / 100 \mathrm{~g}, 0.9 \mathrm{mg} / 100 \mathrm{~g}-14.81 \mathrm{mg} / 100 \mathrm{~g}$ and $0.39 \mathrm{mg} / 100 \mathrm{~g}-2.8 \mathrm{mg} / 100$ respectively. Also, these results confirmed those of Konishi et al. (2004) they reported that quinoa flour contained $86.30 \mathrm{mg} / 100 \mathrm{~g}$ calcium and $4.0 \mathrm{mg} / 100 \mathrm{~g}$ zinc.

\section{Effect of different mixtures of flour on viscoamylograph parameters}

Table (4) presented viscoamylograph values of resulted dough from the control sample (100\% wheat flour $72 \%$ extraction) and the other gluten free dough. The obtained results indicated that, the lowest value of heat of transition $\left(55^{\circ} \mathrm{C}\right)$ was recorded by the resulted dough from quinoa flour while the other samples recorded nearly values which ranged between (60$63^{\circ} \mathrm{C}$ ). Also, the maximum viscosity showed the lowest value by the resulted dough from quinoa flour in contrast to the highest value which recorded by the resulted dough from wheat flour, on other hand the resulted dough from wheat flour recorded the highest values of temperature of maximum viscosity, break down viscosity and set back viscosity $\left(93^{\circ} \mathrm{C}\right.$, 2250 B.U. and 1480 B.U.), respectively.

Table (4):.Effect of different mixtures of flour on viscoamylograph parameters

\begin{tabular}{|c|c|c|c|c|c|}
\hline Samples & $\begin{array}{c}\text { Heat of } \\
\text { transition } \\
\left({ }^{\circ} \mathbf{C}\right)\end{array}$ & $\begin{array}{c}\text { Maximum } \\
\text { viscosity } \\
(\mathbf{B . U .})\end{array}$ & $\begin{array}{c}\text { Temp. of } \\
\text { Maximum } \\
\text { viscosity }\left({ }^{\circ} \mathbf{C}\right)\end{array}$ & $\begin{array}{c}\text { Break down } \\
\text { viscosity } \\
(\mathbf{B . U .})\end{array}$ & $\begin{array}{c}\text { Set back } \\
\text { viscosity } \\
(\mathbf{B . U .})\end{array}$ \\
\hline Control & 63.00 & 1250 & 93.00 & 2250 & 1480 \\
\hline $\mathbf{1}$ & 55.00 & 200 & 87.00 & 190 & 300 \\
\hline $\mathbf{2}$ & 63.00 & 720 & 85.00 & 520 & 500 \\
\hline $\mathbf{3}$ & 60.90 & 520 & 75.00 & 420 & 520 \\
\hline $\mathbf{4}$ & 61.50 & 720 & 85.50 & 720 & 640 \\
\hline $\mathbf{5}$ & 63.00 & 860 & 81.00 & 520 & 860 \\
\hline
\end{tabular}


Where: control $=100 \%$ wheat flour $(72 \%$ ex.), $1=40 \%$ quinoa, $2=30 \%$ quinoa $+10 \%$ papaya, $3=20 \%$ quinoa $+20 \%$ papaya, $4=10 \%$ quinoa $+30 \%$ papaya, $5=40 \%$ papaya.

These results are in agreed with those of Mariotti et al. (2005). They found that Pasting temperature for wheat flour $72 \%$ extraction were $63{ }^{\circ} \mathrm{C}$. Also, Ando et al. (2002) reported that, the gelatinization temperature of quinoa starch ranges from $54^{\circ} \mathrm{C}$ to $71^{\circ} \mathrm{C}$. However, the thermal properties of quinoa flour were not correlated with breakdown and setback, likely was due to other composition factors in the flour, such as protein and fiber (Sandhu and Singh, 2007).

\section{Chemical composition of gluten free biscuit}

Chemical composition of gluten free biscuit samples were determined and the obtained results are shown in Table (5). The results indicated that, the moisture contents were gradually increase where the percentages of papaya powder increased and no significant difference between the gluten free biscuit samples which content $10 \%$ quinoa flour plus $30 \%$ papaya powder and the samples content $40 \%$ papaya powder. While the highest value of ash content (1.85\%) was recorded by the sample content $40 \%$ quinoa flour with significant difference.

Table (5): Chemical composition of gluten free biscuit (on dry weight basis).

\begin{tabular}{|c|c|c|c|c|c|c|}
\hline \multirow{2}{*}{ Samples } & \multicolumn{5}{|c|}{ Chemical composition of biscuit (g/100g) } \\
\cline { 2 - 7 } & Moisture & Ash & Protein & Fat & Fiber & Carbohydrates \\
\hline Control & $3.95^{\mathrm{c}}$ & $0.53^{\mathrm{f}}$ & $8.92^{\mathrm{b}}$ & $17.31^{\mathrm{c}}$ & $0.89^{\mathrm{f}}$ & $72.35^{\mathrm{a}}$ \\
\hline $\mathbf{1}$ & $3.77^{\mathrm{d}}$ & $1.85^{\mathrm{a}}$ & $11.69^{\mathrm{a}}$ & $18.18^{\mathrm{c}}$ & $2.36^{\mathrm{e}}$ & $66.53^{\mathrm{b}}$ \\
\hline $\mathbf{2}$ & $4.01^{\mathrm{b}, \mathrm{c}}$ & $1.72^{\mathrm{b}}$ & $11.51^{\mathrm{a}}$ & $18.86^{\mathrm{b}}$ & $3.05^{\mathrm{d}}$ & $65.16^{\mathrm{b}}$ \\
\hline $\mathbf{3}$ & $4.12^{\mathrm{b}}$ & $1.58^{\mathrm{c}}$ & $11.36^{\mathrm{a}}$ & $19.61^{\mathrm{b}}$ & $3.82^{\mathrm{c}}$ & $63.63^{\mathrm{b}}$ \\
\hline $\mathbf{4}$ & $4.33^{\mathrm{a}}$ & $1.42^{\mathrm{d}}$ & $11.21^{\mathrm{a}}$ & $20.44^{\mathrm{a}}$ & $4.66^{\mathrm{b}}$ & $61.97^{\mathrm{c}}$ \\
\hline $\mathbf{5}$ & $4.39^{\mathrm{a}}$ & $1.25^{\mathrm{e}}$ & $11.08^{\mathrm{a}}$ & $21.36^{\mathrm{a}}$ & $5.60^{\mathrm{a}}$ & $60.10^{\mathrm{c}}$ \\
\hline $\begin{array}{c}\text { LSD at } \\
\mathbf{0 . 0 5}\end{array}$ & $\mathbf{0 . 1 0 5}$ & $\mathbf{0 . 0 9 1}$ & $\mathbf{0 . 6 0 6}$ & $\mathbf{1 . 1 5 4}$ & $\mathbf{0 . 0 9 4}$ & $\mathbf{3 . 5 1 4}$ \\
\hline
\end{tabular}

The same letter in the same column are not significantly different at $\mathrm{P} \leq 0.05$.

Where: control $=100 \%$ wheat flour $(72 \%$ ex.), $1=40 \%$ quinoa, $2=30 \%$ quinoa $+10 \%$ papaya, $3=20 \%$ quinoa $+20 \%$ papaya, $4=10 \%$ quinoa $+30 \%$ papaya, $5=40 \%$ papaya. 
Concerning the fat and fiber content, these results indicated that the gluten free biscuit sample contained $40 \%$ papaya powder recorded the highest values of fat and fiber content with significant differences (21.36 and $5.60 \%$ respectively). While the control samples of biscuit (wheat flour $72 \%$ ) recorded lowest values of ash, protein and fiber content with significant differences. The chemical composition of control biscuit was in agreement with those reported by Youssef (2015) he reported that wheat biscuit contained $3.75 \%$ moisture, $9.11 \%$ protein, $1.00 \%$ fiber and $77.19 \%$ total carbohydrates. Also, Brito et al. (2015) reported that quinoa flour let to increase ash and fiber content and decrease the total carbohydrate content compared to the biscuit produced from wheat flour as a control. Also, these results were in agreement with those of Yusufu and Akhigbe (2014) they reported that the replacement of wheat flour by different levels of papaya powder led to increase protein, ash, fiber contents in the produced biscuit.

\section{Mineral contents of gluten free biscuit produced from flour mixtures}

From the results presented in Table (6) it could be noticed that, according to the statistical analysis, all biscuit samples were significantly varied for calcium and iron contents. Whereas, the highest value of calcium was presented by the gluten free biscuit sample contained $40 \%$ papaya powder on contrary to control sample $(242.14$ and $71.96 \mathrm{mg} / 100 \mathrm{~g}$ respectively) while, the higher values of iron content were recorded by the gluten free biscuit samples contained $10 \%$ quinoa flour plus $30 \%$ papaya powder and the gluten free biscuit sample contained $40 \%$ papaya powder with no significant differences (12.24 and $12.92 \mathrm{mg} / 100 \mathrm{~g}$ respectively). These results were agreement with those of Brito et al. (2015) they reported that the gluten-free quinoa-based cookies were found to be a good source of fiber and minerals.

\section{Baking quality of gluten free biscuit}

Results in Table (7) showed the weight $(\mathrm{g})$, volume $\left(\mathrm{cm}^{3}\right)$, specific volume $(\mathrm{v} / \mathrm{w})$, diameter $(\mathrm{cm})$, thickness $(\mathrm{cm})$ and spread ratio $(\%)$ of gluten-free biscuits. The results indicated that no evident discrepancy was observed for instrumental weight, volume, diameters and thickness between the control biscuit and the other gluten free biscuit samples according to statistical analysis.

However, the higher values of specific volume were recorded by the control biscuit sample and the gluten free biscuit sample which contained $40 \%$ quinoa flour (1.75 and $1.72 \mathrm{~cm} 3 / \mathrm{g}$ respectively) with no significant 
differences, while the other samples where gradually decreased in the same character by increasing of papaya powder.

Table (6): Mineral content of gluten free biscuit samples (on dry weight basis).

\begin{tabular}{|c|c|c|c|}
\hline \multirow{2}{*}{ Samples } & \multicolumn{3}{|c|}{ Mineral content (mg/100g) } \\
\cline { 2 - 4 } & Ca & Fe & Zn \\
\hline Control & $71.96^{\mathrm{f}}$ & $1.74^{\mathrm{e}}$ & $2.08^{\mathrm{e}}$ \\
\hline $\mathbf{1}$ & $165.5^{\mathrm{e}}$ & $7.78^{\mathrm{d}}$ & $4.10^{\mathrm{a}}$ \\
\hline $\mathbf{2}$ & $185.32^{\mathrm{d}}$ & $9.60^{\mathrm{c}}$ & $3.48^{\mathrm{b}}$ \\
\hline $\mathbf{3}$ & $209.02^{\mathrm{c}}$ & $10.58^{\mathrm{b}}$ & $2.86^{\mathrm{c}}$ \\
\hline $\mathbf{4}$ & $222.62^{\mathrm{b}}$ & $12.24^{\mathrm{a}}$ & $2.30^{\mathrm{d}}$ \\
\hline $\mathbf{5}$ & $242.14^{\mathrm{a}}$ & $12.92^{\mathrm{a}}$ & $1.70^{\mathrm{f}}$ \\
\hline LSD at $\mathbf{0 . 0 5}$ & $\mathbf{1 1 . 9 9 1}$ & $\mathbf{0 . 8 6 1}$ & $\mathbf{0 . 0 9 7}$ \\
\hline
\end{tabular}

The same letter in the same column are not significantly different at $\mathrm{P} \leq 0.05$.

Where: control $=100 \%$ wheat flour $(72 \%$ ex. $), \quad 1=40 \%$ quinoa, $2=30 \%$ quinoa $+10 \%$ papaya, $3=20 \%$ quinoa $+20 \%$ papaya, $4=10 \%$ quinoa $+30 \%$ papaya, $5=40 \%$ papaya.

Table (7): Baking quality of gluten free biscuit.

\begin{tabular}{|c|c|c|c|c|c|c|}
\hline \multirow{2}{*}{ Samples } & \multicolumn{7}{|c|}{ Parameters } \\
\cline { 2 - 7 } & $\begin{array}{c}\text { Weight } \\
(\mathbf{g})\end{array}$ & $\begin{array}{c}\text { Volume } \\
\left(\mathbf{c m}^{\mathbf{3}}\right)\end{array}$ & $\begin{array}{c}\text { Specific } \\
\text { volume }(\mathbf{v l w})\end{array}$ & $\begin{array}{c}\text { Diameter } \\
(\mathbf{c m})\end{array}$ & $\begin{array}{c}\text { Thickness } \\
(\mathbf{c m})\end{array}$ & $\begin{array}{c}\text { Spread } \\
\text { ratio }\end{array}$ \\
\hline Control & $10.85^{\mathrm{a}}$ & $19.00^{\mathrm{a}}$ & $1.75^{\mathrm{a}}$ & $6.30^{\mathrm{a}}$ & $0.65^{\mathrm{a}}$ & $9.69^{\mathrm{b}}$ \\
\hline $\mathbf{1}$ & $11.03^{\mathrm{a}}$ & $19.00^{\mathrm{a}}$ & $1.72^{\mathrm{a}}$ & $6.00^{\mathrm{a}}$ & $0.61^{\mathrm{a}}$ & $9.84^{\mathrm{b}}$ \\
\hline $\mathbf{2}$ & $11.50^{\mathrm{a}}$ & $19.00^{\mathrm{a}}$ & $1.65^{\mathrm{ab}}$ & $6.20^{\mathrm{a}}$ & $0.63^{\mathrm{a}}$ & $9.84^{\mathrm{b}}$ \\
\hline $\mathbf{3}$ & $11.43^{\mathrm{a}}$ & $18.50^{\mathrm{a}}$ & $1.62^{\mathrm{b}}$ & $6.10^{\mathrm{a}}$ & $0.63^{\mathrm{a}}$ & $9.68^{\mathrm{b}}$ \\
\hline $\mathbf{4}$ & $11.05^{\mathrm{a}}$ & $18.00^{\mathrm{a}}$ & $1.63^{\mathrm{b}}$ & $6.20^{\mathrm{a}}$ & $0.62^{\mathrm{a}}$ & $10.00^{\mathrm{a}}$ \\
\hline $\mathbf{5}$ & $11.30^{\mathrm{a}}$ & $18.00^{\mathrm{a}}$ & $1.59^{\mathrm{b}}$ & $6.20^{\mathrm{a}}$ & $0.61^{\mathrm{a}}$ & $10.16^{\mathrm{a}}$ \\
\hline LSD at 0.05 & $\mathbf{0 . 8 5 2}$ & $\mathbf{1 . 6 5 4}$ & $\mathbf{0 . 0 9 4}$ & $\mathbf{0 . 4 2 7}$ & $\mathbf{0 . 0 5 4}$ & $\mathbf{0 . 2 8 5}$ \\
\hline
\end{tabular}

The same letter in the same column are not significantly different at $\mathrm{P} \leq 0.05$.

Where: control $=100 \%$ wheat flour $(72 \%$ ex.), $1=40 \%$ quinoa, $2=30 \%$ quinoa $+10 \%$ papaya, $3=20 \%$ quinoa $+20 \%$ papaya, $4=10 \%$ quinoa $+30 \%$ papaya, $5=40 \%$ papaya.

However, the gluten free biscuit samples contained $10 \%$ quinoa flour plus $30 \%$ papaya powder and sample contained $40 \%$ papaya powder recorded the higher values of spread ratio (10.00 and 10.16 respectively) with no significant differences. 
These results were in agreement with those of Yusufu and Akhigbe (2014) they reported that the addition of papaya powder to wheat flour had no significant difference in case of volume, diameters and thickness.

\section{Color values of gluten free biscuit}

The color of the biscuits is one of the characteristics is firstly perceived by the consumer and affects the acceptability of the product. Therefore, the Hunter parameters $\mathrm{L}^{*}, \mathrm{a}^{*}$ and $\mathrm{b}^{*}$ of biscuits were determined and the obtained results are shown in Table (8). The obtained results indicated that, the control biscuits sample showed higher value of $\mathrm{L}^{*}$ and it was 75.77 (more lightness) compared to the $\mathrm{L}^{*}$ value of gluten free biscuit sample which contained 40\% quinoa was recorded 61.96 (less lightness), likewise, $b^{*}$ values(yellowness) which appear the highest value with control sample (36.91) with significant difference compared to the other samples. However, the lightness color was decreased with the increase of papaya powder, on contrary of $a^{*}$ values (redness) which as with the increase of papaya powder in gluten free biscuit samples.

These results in agreement with those of Abou-Zaid et al. (2012) they reported that with the increasing the percentage of added quinoa meal to wheat flours, led to decrease the values of lightness ( $\left.\mathrm{L}^{*}\right)$ and yellowness (b*) slightly in all fortified samples. Also, Thejasri et al. (2017) reported that, the addition of quinoa flour to wheat flour led to decrease the lightness of gluten free biscuit samples and they approved that to the higher value of protein in quinoa flour compared to wheat flour.

Table (8): Color values of gluten free biscuits.

\begin{tabular}{|c|c|c|c|}
\hline \multirow{2}{*}{ Biscuit samples } & \multicolumn{3}{|c|}{ Parameters } \\
\cline { 2 - 4 } & $\mathbf{L}^{*}$ & $\mathbf{a}^{*}$ & $\mathbf{b}^{*}$ \\
\hline \multirow{2}{*}{ Control } & $75.77^{\mathrm{a}}$ & $7.01^{\mathrm{e}}$ & $36.91^{\mathrm{a}}$ \\
\hline $\mathbf{1}$ & $61.96^{\mathrm{b}}$ & $9.25^{\mathrm{d}}$ & $32.69^{\mathrm{b}}$ \\
\hline $\mathbf{2}$ & $53.33^{\mathrm{c}}$ & $12.69^{\mathrm{c}}$ & $29.56^{\mathrm{c}}$ \\
\hline $\mathbf{3}$ & $50.48^{\mathrm{c}}$ & $14.78^{\mathrm{b}}$ & $26.55^{\mathrm{d}}$ \\
\hline $\mathbf{4}$ & $41.65^{\mathrm{d}}$ & $15.08^{\mathrm{a}}$ & $24.13^{\mathrm{d}}$ \\
\hline $\mathbf{5}$ & $35.91^{\mathrm{d}}$ & $16.33^{\mathrm{a}}$ & $22.81^{\mathrm{e}}$ \\
\hline LSD at $\mathbf{0 . 0 5}$ & $\mathbf{7 . 5 2 9}$ & $\mathbf{1 . 3 0 7}$ & $\mathbf{2 . 5 4 8}$ \\
\hline
\end{tabular}


The same letter in the same column are not significantly different at $\mathrm{P} \leq 0.05$.

Where: control $=100 \%$ wheat flour $(72 \%$ ex.),$\quad 1=40 \%$ quinoa, $2=30 \%$ quinoa $+10 \%$ papaya, $3=20 \%$ quinoa $+20 \%$ papaya, $4=10 \%$ quinoa $+30 \%$ papaya, $5=40 \%$ papaya.

\section{Organoleptic characteristics of gluten free biscuit}

Gluten free biscuit samples produced were sensory evaluated for color, taste, odor, texture, appearance and overall acceptability. The obtained results are shown in Table (9) indicated that, no significant differences in color between the control sample and the gluten free biscuit sample contained $40 \%$ quinoa flour sample (1).

Table (9): Organoleptic characteristics of gluten free biscuit.

\begin{tabular}{|c|c|c|c|c|c|c|}
\hline Samples & $\begin{array}{c}\text { Color } \\
(\mathbf{2 0})\end{array}$ & $\begin{array}{c}\text { Taste } \\
(\mathbf{2 0})\end{array}$ & $\begin{array}{c}\text { Odor } \\
(\mathbf{2 0})\end{array}$ & $\begin{array}{c}\text { Texture } \\
(\mathbf{2 0})\end{array}$ & $\begin{array}{c}\text { Appearance } \\
(\mathbf{2 0})\end{array}$ & $\begin{array}{c}\text { Overall } \\
\text { acceptability } \\
(\mathbf{1 0 0})\end{array}$ \\
\hline Control & $18.95^{\mathrm{a}}$ & $19.33^{\mathrm{a}}$ & $19.55^{\mathrm{a}}$ & $18.85^{\mathrm{a}}$ & $18.90^{\mathrm{a}}$ & $96.50^{\mathrm{a}}$ \\
\hline $\mathbf{1}$ & $18.10^{\mathrm{a}}$ & $16.55^{\mathrm{d}}$ & $18.80^{\mathrm{a}}$ & $18.50^{\mathrm{a}}$ & $18.41^{\mathrm{a}}$ & $81.50^{\mathrm{c}}$ \\
\hline $\mathbf{2}$ & $17.20^{\mathrm{b}}$ & $17.30^{\mathrm{b}, \mathrm{dd}}$ & $19.00^{\mathrm{a}}$ & $18.11^{\mathrm{a}}$ & $18.00^{\mathrm{b}}$ & $83.50^{\mathrm{c}}$ \\
\hline $\mathbf{3}$ & $17.00^{\mathrm{b}}$ & $17.63^{\mathrm{b}}$ & $18.42^{\mathrm{b}}$ & $17.97^{\mathrm{b}}$ & $17.64^{\mathrm{b}}$ & $87.59^{\mathrm{b}}$ \\
\hline $\mathbf{4}$ & $16.23^{\mathrm{c}}$ & $16.52^{\mathrm{c}, \mathrm{d}}$ & $18.05^{\mathrm{b}}$ & $16.56^{\mathrm{c}}$ & $16.29^{\mathrm{c}}$ & $80.60^{\mathrm{c}}$ \\
\hline $\mathbf{5}$ & $14.50^{\mathrm{d}}$ & $13.52^{\mathrm{e}}$ & $17.21^{\mathrm{c}}$ & $16.08^{\mathrm{c}}$ & $14.62^{\mathrm{d}}$ & $70.45^{\mathrm{d}}$ \\
\hline $\mathbf{L S D}$ at & $\mathbf{0 . 7 6 0}$ & $\mathbf{0 . 7 5 7}$ & $\mathbf{0 . 7 9 9}$ & $\mathbf{0 . 8 1 7}$ & $\mathbf{0 . 7 2 2}$ & $\mathbf{3 . 1 7 8}$ \\
\hline
\end{tabular}

The same letter in the same column with are not significantly different at $\mathrm{P} \leq 0.05$.

Where: control $=100 \%$ wheat flour $(72 \%$ ex.), $1=40 \%$ quinoa, $2=30 \%$ quinoa $+10 \%$ papaya, $3=20 \%$ quinoa $+20 \%$ papaya, $4=10 \%$ quinoa $+30 \%$ papaya, $5=40 \%$ papaya

Also, no significant differences in color between the sample (2) contained $30 \%$ quinoa flour plus $10 \%$ papaya powder and the gluten free biscuit sample (3) contained $20 \%$ quinoa flour plus $20 \%$ papaya powder $(17.20$ and 17.00 respectively). Whereas, the taste character showed the highest value with control sample (19.33) with significant difference compared to other gluten free biscuit samples which ranged between 17.63 in the sample (3) contained $20 \%$ quinoa flour plus $20 \%$ papaya powder to the lowest value (13.52) in the sample (5) contained $40 \%$ papaya powder. Concerning to odor and texture, the obtained results indicated that no significant difference between the control sample and the sample (1) contained $40 \%$ quinoa flour and the sample (2) contained $30 \%$ quinoa flour plus $10 \%$ papaya powder in 
the same characteristics. Moreover, no significant difference between the biscuit sample (2) produced from $30 \%$ quinoa flour plus $10 \%$ papaya powder and the gluten free biscuit sample (3) contained 20\% quinoa flour plus $20 \%$ papaya powder in appearance character, whereas the control sample recorded the highest value of overall acceptability (96.50) followed by the gluten free biscuit sample (3) contained $20 \%$ quinoa flour plus $20 \%$ papaya powder (87.59). And according to the results of Pathak, et al., (2018), they studied the effect of papaya pulp powder on the quality of biscuit with different substitution levels to wheat flour and they reported that, the produced biscuit recorded high score concerning the taste and overall acceptability and the biscuit was almost same to the control sample.

Conclusively, celiac disease is an autoimmune disorder characterized by intolerance to gluten. Gluten free flours mixtures could be used to produce good quality gluten free biscuit with acceptable physical and sensory qualities. The blends of flours (quinoa flour, papaya powder) at ratio 20:20 or 30:10 respectively are more suitable for produce gluten free biscuit in terms of sensory evaluation. Also, the nutritional values (protein, ash, fiber, iron, calcium and zinc) were increased in the gluten free biscuit compared to the control sample, on contrary to the percentage of carbohydrate content which decreased in the all samples compared to control. However, no evident discrepancy was observed for instrumental weight, volume, diameters and thickness between the gluten free biscuit and the control biscuit. Thus, the produced gluten free biscuits are suitable for those people suffering from celiac disease especially for children with zinc, calcium and iron deficiency.

\section{REFERENCES}

A.A.C.C. (2000). Approved Method of the AACC. ${ }^{10}$ th ed., American Association of Cereal Chemists, INC. st., Paul, Minnesota, USA.

Abdel-Moemin, A. R. (2015). Healthy cookies from cooked fish bones. Food bioscience, 12, 114-121.

Abou-Zaid, A. A., El-Faham, S. Y., \& Emam, W. H. (2012). Use of quinoa meal to produce bakery products to celiac and autism stuffs. International Journal of Science and Research, 3(9), 1344-1354.

Adubofuor, J., Mensah, M. A., \& Dabri, S. (2012). Nutritional and physicochemical properties of partially dried ripe pawpaw pulp and assessing the physical properties of rock buns and cakes prepared from the pawpaw pulp incorporated into wheat 
flour. African Journal of Food Science and Technology, 3(10) 244-251.

Al Shehry, G. A. (2016). Use of corn and quinoa flour to produce bakery products for celiac disease. Advances in Environmental Biology, 10(12), 237-244.

Ando, H., Chen, Y. C., Tang, H., Shimizu, M., Watanabe, K., \& Mitsunaga, T. (2002). Food components in fractions of quinoa seed. Food Science and Technology Research, 8(1), 80-84.

Brito, I. L., de Souza, E. L., Felex, S. S. S., Madruga, M. S., Yamashita, F., \& Magnani, M. (2015). Nutritional and sensory characteristics of gluten-free quinoa (Chenopodium quinoa Willd)-based cookies development using an experimental mixture design. Journal of food science and technology, 52(9), 5866-5873.

Chapman, H. D., \& Pratt, P. F. (1962). Methods of analysis for soils, plants and waters. Soil Science, 93(1), 68.

FAOSTAT (2008). Food and agriculture organisation for the united nations - statistics online website. http://faostat.fao.org.

Hussein, A. M. S., Ali, H. S., Bareh G. F., \& Al-Khalifa, A. S. (2011). Physicochemical, sensory and functional properties of gelatinized corn-triticale flour composite tortilla. Australian Journal of Basic and Applied Sciences, 5(11), 43-54.

Karyotis, T., Iliadis, C., Noulas, C., \& Mitsibonas, T. (2003). Preliminary research on seed production and nutrient content for certain quinoa varieties in a saline-sodic soil. Journal of Agronomy and Crop Science, 189(6), 402-408.

Konishi, Y., Hirano, S., Tsuboi, H., \& Wada, M. (2004). Distribution of minerals in quinoa (Chenopodium quinoa Willd.) seeds. Bioscience, biotechnology, and biochemistry, 68(1), 231-234

Larmond, E. (1977). Laboratory methods for sensory evaluation of food. Research Branch, Canada Dept. of Agriculture.

Mariotti, M., Zardi, M., Lucisano, M., \& Pagani, M. A. (2005). Influence of the heating rate on the pasting properties of various flours. Starch-Stärke, 57(11), 564-572.

Mirhosseini, H., Rashid, N. F. A., Amid, B. T., Cheong, K. W., Kazemi, M., \& Zulkurnain, M. (2015). Effect of partial replacement of corn flour with durian seed flour and pumpkin flour on cooking yield, texture properties, and sensory attributes of gluten free pasta. $L W T$ Food Science and Technology, 63(1), 184-190.

Niewinski, M. M. (2008). Advances in celiac disease and gluten-free diet. Journal of the American Dietetic Association, 108(4), 661-672. 
Pathak,R., Thakur, V., \& Gupta, R. K. (2018). Formulation and analysis of papaya fortified biscuits. Journal of Pharmacognosy and Phytochemistry, 7(4), 1542-1545.

Puwastien, P., Burlingame, B., Raroengwichit, M., \& Sungpuag, P. (2000). ASEAN Food Composition Tables of Nutrition, Mahidol University, Thailand.

QECD (2010). Consensus document on compositional consideration for new varieties of papaya Carica papaya: Key food and feed nutrients, anti-nutrients, toxicants and allergens. Environment Directorate Joint Meeting of the Chemicals Committee and the Working Party on Chemicals, Pesticides and Biotechnology. http://78.41.128.130/dataoecd/16/28/46815336.pdf.

Rattanathanalerk, M., Chiewchan, N., \& Srichumpoung, W. (2005). Effect of thermal processing on the quality loss of pineapple juice. Journal of Food engineering, 66(2), 259-265.

Rinaldoni, A. N., Palatnik, D. R., Zaritzky, N., \& Campderrós, M. E. (2014). Soft cheese-like product development enriched with soy protein concentrates. LWT-Food science and Technology, 55(1), 139147.

Roberts, M., Minott, D. A., Tennant, P. F., \& Jackson, J. C. (2008). Assessment of compositional changes during ripening of transgenic papaya modified for protection against papaya ringspot virus. Journal of the Science of Food and Agriculture, 88(11), 1911-1920.

Sandhu, K. S., \& Singh, N. (2007). Some properties of corn starches II: Physicochemical, gelatinization, retrogradation, pasting and gel textural properties. Food Chemistry, 101(4), 1499-1507.

Sansone, F., Picerno, P., Mencherini, T., Russo, P., Gasparri, F., Giannini, V., \& Aquino, R. P. (2013). Enhanced technological and permeation properties of a microencapsulated soy isoflavones extract. Journal of Food Engineering, 115(3), 298-305.

Sapers, G. M., \& Douglas, F. W. (1987). Measurement of enzymatic browning at cut surfaces and in juice of raw apple and pear fruits. Journal of Food Science, 52(5), 1258-1285.

Schober, T. J., O'brien, C. M., McCarthy, D., Darnedde, A., \& Arendt, E. K. (2003). Influence of gluten-free flour mixes and fat powders on the quality of gluten-free biscuits. European Food Research and Technology, 216(5), 369-376. 
Sharoba, A. M. A., El-Desouky, A. I., Mahmoud, M. H. M., \& Youssef, K. M. (2009). Quality attributes of some breads made from wheat flour substituted by different levels of whole amaranth meal. J. Agric. Sci. Mansoura Univ, 34(6), 6601-6617.

Tang, Y., Li, X., Chen, P. X., Zhang, B., Hernandez, M., Zhang, H., \& Tsao, R. (2015). Characterization of fatty acid, carotenoid, tocopherol/tocotrienol compositions and antioxidant activities in seeds of three Chenopodium quinoa Willd. genotypes. Food chemistry, 174, 502-508.

Thejasri, V., Hymavathi, T. V., Roberts, T. P., Anusha, B., \& Devi, S. S. (2017). Sensory, Physico-Chemical and Nutritional Properties of Gluten Free Biscuits Formulated with Quinoa (Chenopodium quinoa Willd.), Foxtail Millet (Setaria italica) and Hydrocolloids. Int. J. Curr. Microbiol. App. Sci, 6(8), 1710-1721.

USDA (United States Department of Agriculture), Agricultural Research Service (2009). National Nutrient Database for Standard Reference, Release 22, Nutrient Data Laboratory Home Page, http://www.ars.usda.gov/ba/bhnrc/ndl.

Varastegani, B., Zzaman, W., \& Yang, T. A. (2015). Investigation on physicochemical and sensory evaluation of cookies substituted with papaya pulp flour. Journal of Food Quality, 38(3), 175-183.

Vega-Gálvez, A., Miranda, M., Vergara, J., Uribe, E., Puente, L., \& Martínez, E. A. (2010). Nutrition facts and functional potential of quinoa (Chenopodium quinoa willd.), an ancient Andean grain: a review. Journal of the Science of Food and Agriculture, 90(15), 25412547.

Vidal-Quintanar, R. L., Love, J., \& Johnson, L. A. (2001). Role of oil on physical properties of corn masa flours and sensory characteristics of corn tortillas. Journal of food processing and preservation, 25(1), 1-14.

Waszczuk, E., Kosiara, M., Dobosz, T., \& Paradowski, L. (2007). Celiac disease and diabetes mellitus. Advances in Clinical and Experimental Medicine, 16(2), 297-301.

Youssef, H. M. (2015). Assessment of gross chemical composition, mineral composition, vitamin composition and amino acids composition of wheat biscuits and wheat germ fortified biscuits. Food and Nutrition Sciences, 6(10), 845-853.

Yusufu, M. I., \& Akhigbe, A. O. (2014). The Production of Pawpaw Enriched Cookies: Functional, Physico-Chemical and Sensory characteristics. Asian Journal of Agriculture and Food Science, 2(2), $100-106$. 


\section{إعداد وتقييم الخواص الطبيعية والكيميائية للبسكويت الخالي من الجلوتين \\ هدير عبدالحميد أحمد عبدالحميد' ـ عبدالجواد محمد محمد الثواف' ـ عطيه محمد المخزنجى'

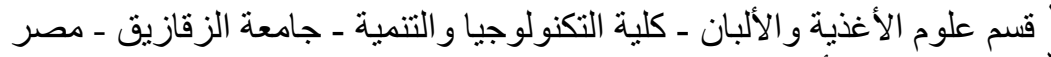

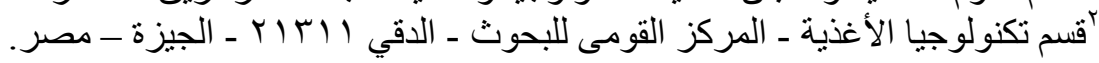

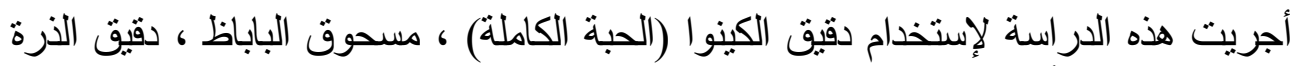

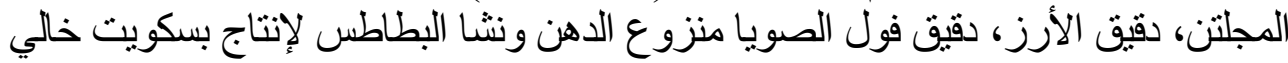

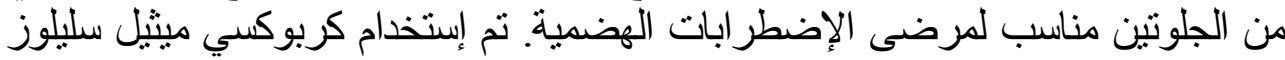

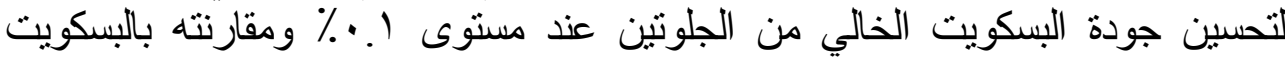

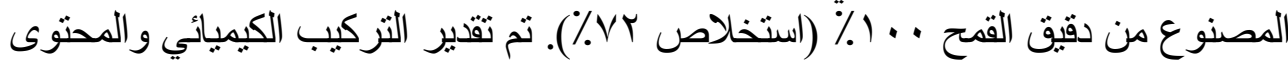

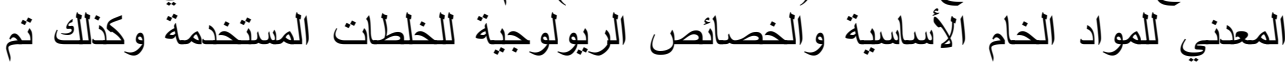

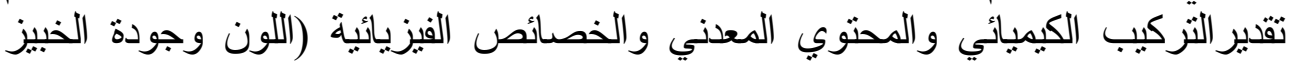
و والتقييم الحسي) للمنتج النهائي.

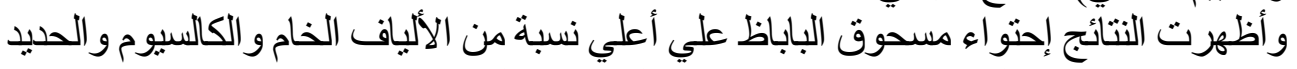

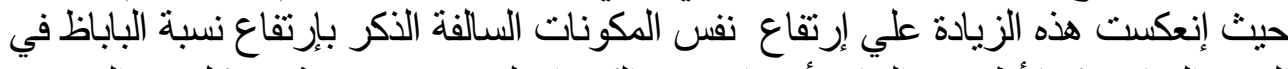

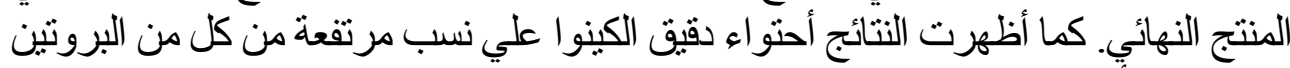

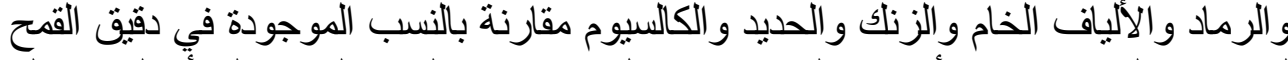

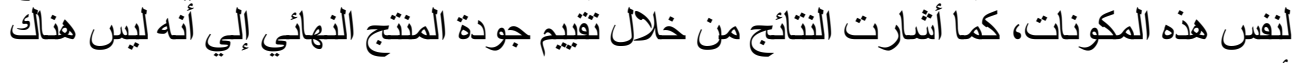

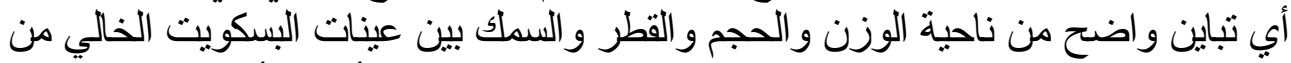

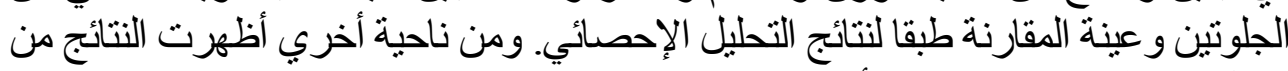

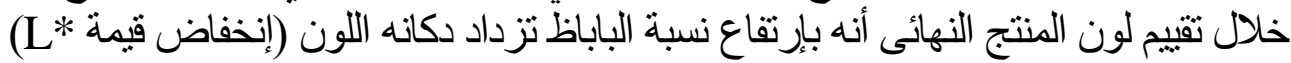

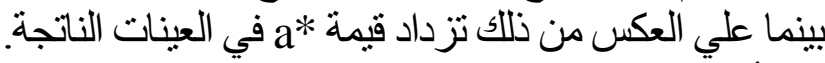

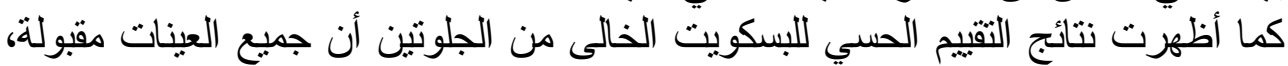

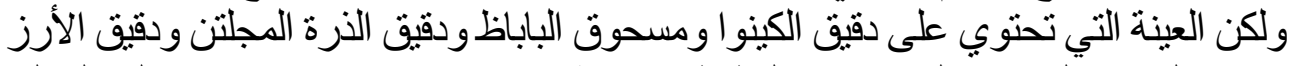

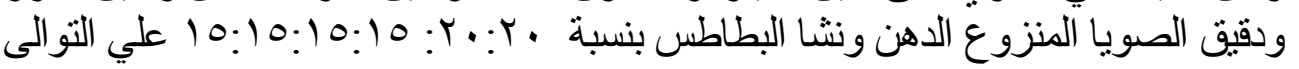

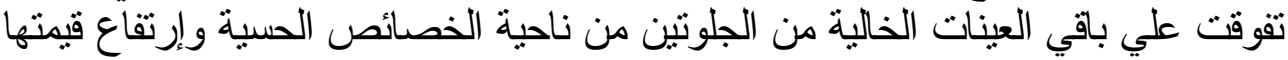

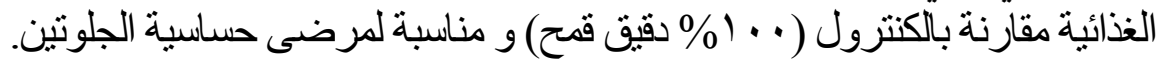

